\title{
ZNACZENIE PRAKTYK PEDAGOGICZNYCH DLA ZMIAN W OBSZARZE KLUCZOWYCH KOMPETENCJI NAUCZYCIELA EDUKACJI PRZEDSZKOLNEJ I WCZESNOSZKOLNEJ
}

\begin{abstract}
AвSTRACT. Sikorska Joanna, Schmidt Anna, Znaczenie praktyk pedagogicznych dla zmian w obszarze kluczowych kompetencji nauczyciela edukacji przedszkolnej i wczesnoszkolnej [The Importance of Pedagogical Practicum for Change in the Area of Key Competences of Preschool and Elementary School Teachers]. Studia Edukacyjne nr 49, 2018, Poznań 2018, pp. 445-462. Adam Mickiewicz University Press. ISSN 1233-6688. DOI: 10.14746/se.2018.49.26
\end{abstract}

The future teacher, wanting to understand the child's needs, his pursuit of self-realization and autonomy must build himself not only on theoretical knowledge, but also learn how to use this knowledge in educational practicum. In this context, preparing student teachers "through practicum for practicum" seems to be an extremely important element of their education, because only in this way will they be able to stimulate their own development, mature professionally, but also answer the question to what extent "being a teacher" is their true calling. Student teachers, especially those who have practicum in grades 1-3 of elementary school, pay more attention to the gradual departure in many institutions from the implementation of the concept of integrated education. The information obtained by them indicates that the "modifications" of the model of this education are largely caused by anxiety caused by low results achieved by children in tests aimed at checking the effectiveness of education. Undoubtedly, this is a cause for serious concern and remedial action, however, according to our research, many students are concerned that during lectures or even laboratories, run by some specialists realizing specific subjects, they are only passive observers and have no opportunity to learn how to, in school conditions, complementarily combine tasks from many educational areas, in accordance with the assumptions of integral education. Thus, there is a significant discrepancy between the tasks carried out as part of classes at the university and pedagogical practicum.

The authors of the article focus on both theoretical aspects of the issues raised and the results of their own research.

Key words: pedagogical practicum, preparation for practicum, teacher of a preschool and early school aged child, educational reality, research on students' expectations related to pedagogical practicum 


\section{Wprowadzenie}

Coraz częściej pedeutolodzy, jak i nauczyciele - praktycy zwracają uwagę na fakt, że kształcenie nauczycieli znalazło się na rozdrożu. Szczególne wyzwanie staje przed szkolnictwem wyższym kształcącym nauczycieli edukacji elementarnej, która ze względu na swą specyfikę wymaga nie tylko kompetencji związanych z umiejętnością integrowania przez przyszłych nauczycieli wiedzy z różnych dziedzin, ale także zrozumienia potrzeb dziecka, jego dążenia do samorealizacji i autonomii, zaufania do twórczego potencjału dzieci. Przyszły nauczyciel chcąc sprostać tym zadaniom, musi więc budować nie tylko wiedzę teoretyczną, ale także uczyć się, jak tę wiedzę wykorzystywać w praktyce edukacyjnej. W tym kontekście niezmiernie istotnym elementem kształcenia przyszłego nauczyciela wydaje się jego przygotowanie „przez praktykę dla praktyki”, bo tylko w ten sposób będzie mógł jednocześnie stymulować własny rozwój, dojrzewać zawodowo, ale też odpowiedzieć na pytanie: w jakim stopniu „bycie nauczycielem” jest jego autentycznym powołaniem.

\section{Kompetentny nauczyciel dziecka w wieku przedszkolnym i wczesnoszkolnym, czyli kto?}

Koncepcja edukacji zintegrowanej jest głęboko osadzona w teorii uczenia się i rozwoju w okresie późnego dzieciństwa, a szczególnie w konstruktywizmie (Jerome Bruner, Jean Piaget, Lew Wygotski, Erik Erikson, H. Rudolph Schaffer, Anna Brzezińska, Maria Tyszkowa, Dorota Klus-Stańska i inni). Jest to spójna, całościowa koncepcja odwołująca się do najnowszych odkryć w dziedzinach podstawowych dla efektywnego uczenia się, na przykład neurobiologii, czy neuropsychologii, które dobrze definiują mechanizmy rozwoju dziecka, doprowadzające do zmian w jego psychofizycznym funkcjonowaniu oraz $w$ tych dziedzinach, które opisują niezbędne warunki zewnętrzne, $\mathrm{w}$ jakich te mechanizmy mogą być uruchamiane w toku edukacji.

Zgodnie z założeniami, kształcenie zintegrowane, do realizacji którego przygotowywani są także studenci specjalności nauczycielskich na Wydziale Studiów Edukacyjnych UAM, to organizacja procesów edukacyjnych polegających na tworzeniu dziecku warunków do uczenia się poprzez podejmowanie samodzielnej, wewnętrznie i zewnętrznie scalonej aktywności, w toku realizacji zadań edukacyjnych, wykraczających poza tradycyjnie zdefiniowane dziedziny wiedzy. Ich realizacja wymaga przemyślanego integrowania różnorodnych form aktywności dziecka, podejmowanej we współdziałaniu z nauczycielem i rówieśnikami, a także integracji różnych podmiotów znaj- 
dujących się we wspólnej przestrzeni edukacyjnej szeroko rozumianego środowiska życia dziecka: domowego, rówieśniczego, społecznego, materialno-przyrodniczego, a także medialnego (w tym środowiska TIK).

Współcześni nauczyciele pracujący z małym dzieckiem, poza kompetencjami merytorycznymi i metodycznymi odnoszącymi się do wiedzy, umiejętności i kompetencji społecznych, ukształtowanymi w trakcie studiów i praktyk pedagogicznych oraz zawodowych, a także dalszego doskonalenia zawodowego, powinni cechować się umiejętnością tworzenia takich sytuacji, które pozwolą dziecku (szczególnie temu w okresie wczesnego, średniego i późnego dzieciństwa) możliwie szybko adaptować się do nowej sytuacji fizycznej, społecznej i edukacyjnej. Od nich zależy, w jakim stopniu dziecko będzie aktywne w relacjach z innymi ludźmi w otaczającej go przestrzeni przedszkola i szkoły, a także w środowisku pozainstytucjonalnym ${ }^{1}$. Denise Chauval i Anne-Marie Casanova zauważają, iż

nauczyciel natknie się być może na dzieci inne, niżby oczekiwał, lecz bogate we własne możliwości. Swymi działaniami nie może zamykać, powstrzymywać, przedłużać, powielać. Jego zadaniem jest otwierać, czynić tak, by narodziła się nowa istota, która odciśnie na świecie swoje własne piętno².

W ten sposób zmierzamy ku wzorowi (post)nowoczesnego edukatora, przystającego do europejskiego modelu nauczyciela i przedszkola/szkoły ${ }^{3}$. Współczesne oczekiwania wyznaczają potrzebę przyjęcia przez niego polifonii nowych ról, zadań, pełnienia szerokiej i ciągle uzupełnianej gamy funkcji oraz powinności . Nauczyciel stanął tym samym przed koniecznością odczytania nowych, zadanych, a nie danych mu kompetencji ${ }^{5}$ - kompetencji określanych mianem kluczowych dla funkcjonowania w XXI wieku, nazywanym przez niektórych stuleciem kompetencji.

Już ponad dziesięć lat temu, w roku 2005, zespół powołany przez Komisję Europejską, złożony z przedstawicieli dwudziestu pięciu państw dokonał opisu kompetencji, kwalifikacji i profilu nauczyciela w Unii Europejskiej, określając tym samym zasady odnoszące się do zawodu nauczycielskiego. Stwierdzono, że jest to zawód wymagający wyższego wykształcenia, osadzo-

\footnotetext{
${ }^{1}$ Zob. np. M. Styczyńska, Rola mężczyzny w wychowaniu dziecka w wieku przedszkolnym, [w:] Dziecko sukcesy i porażki, red. R. Piwowarski, Warszawa 2007, s. 264.

2 D. Chauval, A.M. Casanova, Podręcznik przedszkolanki, Warszawa 1998, s. 15-16.

${ }^{3}$ U. Ordon, Nauczyciel w przestrzeni edukacyjnej jednoczacej się Europy, Częstochowa 2007, s. 8-9.

${ }^{4}$ B. Potyrała, Przełom wieków wyzwaniem dla edukacji i nauczyciela, [w:] W poszukiwaniu wyznaczników kompetencji nauczyciela XXI wieku, red. E. Kobyłecka, E. Kozioł, Zielona Góra 2002, s. 35,39 .

${ }^{5}$ J. Gnitecki, Kompetencje i zwiększanie szans edukacyjnych nauczycieli w cyklu życia w warunkach postępującej globalizacji, [w:] Tamże, s. 53.
} 
ny w kontekście Long Life Learning, wymagający mobilności i umiejętności bycia partnerem zarówno dzieci, jak i innych dorosłych. Powyższe rodzaje kompetencji są zgodne z polskimi i europejskimi standardami kształcenia nauczycieli. Jednak, jak podkreśla Wojciech Pasterniak, najważniejszą kompetencją nauczyciela wydaje się jednak jego mądrość, która stanowi podstawę „stawania się kompetentnym". Wszelkie inne kompetencje są jej podporządkowane. W świetle przytoczonej uwagi można więc jednoznacznie stwierdzić, że skończyła się era nauczyciela będącego wyłącznie skarbnicą wiedzy ${ }^{6}$. Powyższe rozważania i opracowania podporządkować można twierdzeniu Zbigniewa Kwiecińskiego, według którego obecnie trzeba przejść do nowoczesnego kształcenia i doskonalenia nauczycieli tak, by odeszli od swych odtwórczych ról przekazicieli wiedzy do twórczych ról przewodników ${ }^{7}$. Przede wszystkim, nauczyciel powinien jednak pozostać sobą.

Ten, kto prowadzi jest przewodnikiem. Ten, kto jest wzorem to przede wszystkim autorytet. Ten, kto współdziała - bywa partnerem. Ten, kto uczy skutecznie - jest po prostu mistrzem. A naprawdę, ten, kto „kocha, lubi, szanuje” - to przede wszystkim prawdziwy, normalny człowiek. Właśnie człowiek, a więc: przewodnik, autorytet, partner, mistrz. Przy czym człowiek cały, niepodzielny ${ }^{8}$.

\section{Moduł „Przygotowanie do praktyki" i „Praktyka pedagogiczna” - wyzwanie dla nauczyciela akademickiego, studenta - przyszłego nauczyciela \\ i jego mentora w placówce edukacyjnej - nauczyciela praktyka}

Założenia dotyczące integralności procesów rozwojowych nie są kwestionowane ani $\mathrm{w}$ nauce, ani w środowiskach edukacyjnych. Tymczasem, obecna szkoła nierzadko odchodzi od ich realizacji. W ramy edukacji integralnej wprowadza się nauczanie przedmiotowe, co w efekcie powoduje, że dziecko nie ma możliwości podejmowania autentycznej, wewnętrznej, a nie tylko pozorowanej i wysoce ustrukturowanej, zewnętrznej aktywności. Doświadczana przez nie rzeczywistość jest już nie tylko w warunkach szkolnych, ale niestety także przedszkolnych, fragmentaryzowana i niespójna. Dziecko na tym etapie rozwoju nie potrafi jeszcze scalić w jedną spójną całość fragmentów rzeczywistości, które poznaje na wydzielonych i rzadko kiedy zintegrowanych obszarach (przedmiotach). Tworzy zatem nierealny obraz świata, daleki

\footnotetext{
${ }^{6}$ W. Pasterniak, Od matego ego do mądrości. O antykompetencjach $i$ kompetencjach edukacyjnych nauczycieli, [w:] Tamże.

${ }^{7}$ K. Szorc, Kompetencje nauczyciela na miare XXI w., 2005 zob: http:/ / konferencja.21.edu.pl/ publikacje/1/360.pdf [dostęp: 17.04.2018].

${ }^{8}$ J. Radziewicz, Autoportret pedagogiczny, Edukacja i Dialog, 1996, 4, s. 28.
} 
od rzeczywistego, w którym czuje się po prostu bezradne i zagubione. Praca zgodnie z koncepcją edukacji zintegrowanej jest niewątpliwie wyzwaniem dla nauczyciela. Wymaga od niego szeregu kompetencji, jak na przykład umiejętności planowania pracy i projektowania scalonych zadań zintegrowanych, krytycznej analizy programów nauczania, diagnozowania potrzeb i możliwości rozwojowych dzieci, ale też monitorowania zmian zachodzących w tym zakresie, prowadzenia zajęć w sposób pozwalający skoncentrować się nauczycielowi zarówno na Ja indywidualnym, jak i społecznym dziecka, co pozwala dostrzegać także dzieci z „ryzyka niepowodzeń w uczeniu się” .

Jednakże, trudności te nie usprawiedliwiają pod żadnym pozorem rezygnacji z realizacji edukacji zintegrowanej, bo prowadzi to do pogwałcenia natury dziecka i mechanizmów jego rozwoju. W tym kontekście jedynym racjonalnym wnioskiem staje się konieczność odpowiedniego przygotowania przyszłych nauczycieli do jej rzetelnej realizacji. Elementem tego przygotowania powinien być moduł łączący przygotowanie do praktyki pedagogicznej/zawodowej, realizowany na uczelni, oraz nauczycielskie praktyki pedagogiczne, odbywane przez studentów w placówkach opieki nad dzieckiem do lat trzech, przedszkolach i szkołach. Ten pierwszy oparty na dyskusji, dialogu ze studentem i mikroteachingu powinien pozwolić studentowi nie tylko dostrzec wagę kompetencji psychopedagogicznych i merytorycznych nauczyciela, ale też rozwinać podstawy tych umiejętności, które będą sprzyjały uczeniu się od nauczyciela - praktyka, samorealizacji w relacjach z dziećmi/ uczniami oraz ich opiekunami, zachęcały do podejmowania wyzwań związanych ze wspieraniem dzieci w podejmowanych przez nie zadaniach. Swoistym wyzwaniem dla nauczycieli akademickich w przygotowaniu studentów do podejmowania działań praktycznych jest też wykorzystanie w tym przygotowaniu nowych narzędzi technologicznych, takich jak eTwinning, czy SimSchool.

Wykorzystanie przez studenta zdobywanych kompetencji i związany z nimi poziom efektywności działań podejmowanych przez niego w praktyce edukacyjnej związany jest jednak zawsze z relacją między nauczycielem - mentorem studenta podejmującego praktykę w przedszkolu/szkole oraz studentem. Profesjonalne kompetencje zdobyte podczas studiów mają bowiem niestety czasem charakter deklaratywny. Praktyka pedagogiczna stwarza jedyną i niepowtarzalną okazję rzeczywistego doświadczania teorii w praktyce, weryfikacji założeń teoretycznych, czy przekonania o posiadanych umiejętnościach podczas działań z dziećmi oraz kontaktów z innymi nauczycielami, praktykantami, rodzicami dzieci, czy specjalistami pracującymi

${ }^{9}$ H. Krauze-Sikorska, Dzieci i młodzież z ryzyka niepowodzeń w uczeniu się w przestrzeni edukacyjnej i społecznej szkoty powszechnej. Systemowe strategie pomocy - (nie)nowe wyzwania, nowe perspektywy - materiał niepublikowany (za zgodą autora) 2018. 
w placówce (m.in. psychologami, logopedami, pedagogami - terapeutami) oraz przeprowadzenia ewaluacji własnych osiągnięć $\mathrm{w}$ warunkach placówki edukacyjnej. Wiedza naukowa i metodyczna zdobyta podczas studiów staje w obliczu dynamicznej praktyki edukacyjnej, która odzwierciedla niedoskonałości i być może zadecyduje o ostatecznym wyborze drogi zawodowej. Praktyka pedagogiczna pozwala nie tylko na refleksję nad osobistymi kompetencjami, ale też, jeśli mentor studenta rozumie jej istotę, na wdrażanie do praktyki przedszkolnej/szkolnej własnych idei, koncepcji i strategii pracy studenta - przyszłego nauczyciela.

Wszelkie doświadczenia praktyczne zdobyte podczas studiów wyższych stają się w obliczu tej dynamiki nieocenione i wyznaczają swoistość działań studenta - przyszłego nauczyciela oraz stanowią przyczynek do formułowania wstępnych sądów wartościujących przygotowanie do zawodu, jak też jakość prezentowanych kompetencji kierunkowych i specjalnościowych.

Efektywność i jakość podejmowanych wyborów zależy od wielu czynników. Artykułowanie problemów podczas praktyki - komunikacja w formułowaniu i formowaniu sądów, spostrzeżeń i uwag - może przyczynić się do budowania lepszej strategii praktyki pedagogicznej, której podstawą będą procesy ewaluacyjne, rozumiane jako badanie wartości własnej pracy. Łatwo dać się uwieść wizji abstrakcyjnych programów studiów i praktyk pedagogicznych, będących często złudną realizacją nierealnych planów osób lub instytucji, natomiast trudno sprostać wymaganiom współczesności, która dynamicznie zmienia się i ewoluuje.

\section{Dlaczego „możliwe” nie zawsze staje się „realne”? \\ - o rozbieżności między oczekiwaniami studentów związanymi z praktyką pedagogiczną a rzeczywistością edukacyjną. Analiza wyników badań dotyczących oceny praktyk pedagogicznych i zawodowych przez studentów pedagogiki oraz pedagogiki specjalnej na Wydziale Studiów Edukacyjnych Uniwersytetu im. Adama Mickiewicza w Poznaniu}

Studenci, szczególnie ci realizujący praktyki w klasach I-III szkoły podstawowej, coraz częściej zwracają uwagę na stopniowe odchodzenie w wielu placówkach od realizacji koncepcji edukacji zintegrowanej. Uzyskane przez nich informacje wskazują, że "modyfikacje” modelu tej edukacji uwarunkowane są w znacznym stopniu niepokojem wywołanym niskimi wynikami osiąganymi przez dzieci w badaniach efektywności kształcenia. Niewątpliwie jest to powód do poważnej troski i podjęcia działań naprawczych, jednak 
jak wskazują nasze badania, wielu studentów niepokoi, że w czasie konwersatoriów, czy nawet laboratoriów prowadzonych przez niektórych specjalistów realizujących określone przedmioty, są jedynie biernymi obserwatorami i nie mają możliwości uczenia się, jak w warunkach szkoły komplementarnie łączyć zadania $\mathrm{z}$ wielu obszarów edukacyjnych, zgodnie z założeniami edukacji integralnej. Pojawia się tym samym znaczna czasem rozbieżność między zadaniami realizowanymi $w$ ramach zajęć na uczelni a praktyką pedagogiczną.

W badaniach, które traktujemy jako swoisty pilotaż przygotowujący do dalszych, pogłębionych ilościowo-jakościowych badań, na temat znaczenia praktyk pedagogicznych i zawodowych dla rozwoju kompetencji kluczowych przyszłych nauczycieli edukacji elementarnej, uczestniczyło 40 studentów pedagogiki oraz pedagogiki specjalnej z Wydziału Studiów Edukacyjnych Uniwersytetu im. Adama Mickiewicza - 37 kobiet oraz 3 mężczyzn w przedziale wiekowym: od 19 do 24 lat. Badanie, przeprowadzone w 2017 roku, miało charakter diagnostyczny. Poddały się jemu wyłącznie osoby chętne. $\mathrm{W}$ analizie uzyskanych $\mathrm{z}$ tej małej próbki danych skupiono się więc nie tyle na wskazaniach ilościowych (prezentowane przez nas wykresy należy potraktować jako wizualną prezentację pewnych istotnych dla dalszych badań danych), ile na podejściu jakościowym, pozwalającym studentom na odniesienie się do osobistych doświadczeń związanych z przygotowaniem do praktyki i realizowaniem zadań $\mathrm{w}$ ramach praktyk $\mathrm{w}$ przedszkolu i szkole.

Studenci biorący udział w badaniu reprezentowali studia zarówno pierwszego, jak i drugiego stopnia (pierwszy stopień: 37 osób, rok I, II oraz III studiów, a także drugi stopień: 3 osoby, rok I i II), a wśród nich następujące kierunki: pedagogika i pedagogika specjalna oraz specjalności: edukacja elementarna i terapia pedagogiczna, edukacja elementarna i wychowanie fizyczne, edukacja elementarna i nauczanie dzieci z niepełnosprawnością intelektualną w stopniu lekkim, wychowanie przedszkolne i nauczanie początkowe, pedagogika wspierająca uczniów ze specjalnymi potrzebami edukacyjnymi, edukacja i rehabilitacja osób z niepełnosprawnością.

Pytania zawarte $\mathrm{w}$ kwestionariuszu ankiety dotyczyły:

- oceny przez studentów realizacji przedmiotu „Przygotowanie do praktyki";

- oceny poziomu realizacji poszczególnych celów odbywanej praktyki, w tym:

- zapoznania się z procedurą projektowania przez nauczyciela działań edukacyjnych i wychowawczo-opiekunczych;

- nabywania umiejętności samodzielnego planowania i prowadzenia zajęć dydaktycznych;

- podejmowania działań opiekuńczo-wychowawczych; 
- zapoznania się z programem i planem pracy nauczyciela;

- zapoznania się z działaniami podejmowanymi na rzecz dzieci z trudnościami w funkcjonowaniu psychospołecznym;

- poznania form pomocy psychologiczno-pedagogicznej funkcjonujących na terenie placówki;

- możliwości samodzielnego planowania i przeprowadzenia zajęć.

Ważnym aspektem analizy była też ocena studentów dotycząca liczby godzin odbywanych praktyk oraz osobista refleksja na temat potrzeby ich zwiększenia i zmniejszenia, wskazanie na własne propozycje zmian w zakresie realizowanych praktyk oraz ocena współpracy z nauczycielem/pedagogiem opiekunem praktyk w placówce edukacyjnej. Wielu istotnych informacji dostarczyły też opisy subiektywnych doświadczeń dotyczących „stawania się kompetentnym nauczycielem" (vs nie) w czasie realizacji praktyk pedagogicznych.

Poniżej przedstawione zostały wyniki dotyczące poszczególnych aspektów badań diagnostycznych. Od analiz ilościowych, prezentujących opinie studentów na temat przygotowania do praktyki i praktyki pedagogicznej realizowanej w placówkach oświatowych, przechodzimy do kilku wybranych opisów ich osobistych doświadczeń związanych z „przygotowaniem do stawania się kompetentnym nauczycielem".

Oceny realizacji przedmiotu „Przygotowanie do praktyki pedagogicznej” studenci dokonali w skali 5-stopniowej, gdzie 1 oznaczało niski stopień zadowolenia, natomiast 5 - wysoki stopień zadowolenia. Oto udzielone odpowiedzi:

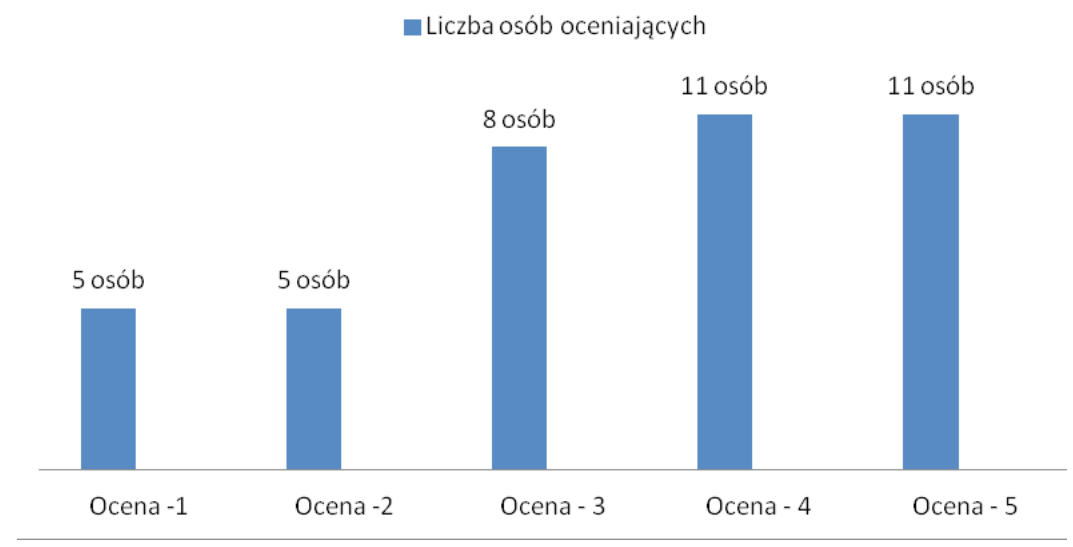

Ryc. 1. Ocena poziomu realizacji przedmiotu:

„Przygotowanie do praktyki pedagogicznej”

(Źródło: opracowanie własne na podstawie przeprowadzonych badań) 
Pięć osób oceniło realizację przedmiotu negatywnie, przyznając notę najniższą - 1. Ocenę 2 przyznało również pięć osób, ocenę dostateczną - 3 dało ośmiu respondentów, natomiast liczbę osób oceniających „Przygotowanie do praktyki" na poziomie dobrym, przyznając notę 4, stanowiło jedenaście osób, a przyznających ocenę najwyższą - 5 również jedenaście osób. Można zatem dostrzec, że pomimo iż większość badanych oceniła realizację przedmiotu pozytywnie - ocena 3, 4 i 5 (łącznie 30 osób), to wśród badanych znalazły się również osoby oceniające ją negatywnie i przyznały noty 1 oraz 2 - razem 10 osób.

Kolejne pytanie stanowiło pytanie uzupełniające i doprecyzowujące. Jego celem było poznanie propozycji zmian studentów nieusatysfakcjonowanych z realizacji przedmiotu: „Przygotowanie do praktyki pedagogicznej”. Studenci wskazali między innymi następujące aspekty:

- zbyt niski poziom wiedzy i kompetencji osoby prowadzącej przedmiot;

- słaby przepływ informacji oraz sposób ich przekazywania - propozycja stworzenia krótkiego „poradnika dotyczącego realizacji praktyk na poszczególnych etapach" (jak daty, miejsca realizacji, dokumentacja, regulaminy);

- zbyt mała liczba spotkań oraz osób odpowiedzialnych za rozliczenie praktyki;

- oceny, otrzymywanej przez studentów - ich zdaniem powinien być to przedmiot na zaliczenie, bez oceny;

- zbyt późna realizacja przedmiotu, a co z tego wynika: zbyt późne otrzymanie konkretnych informacji;

- Liczba osób oceniających

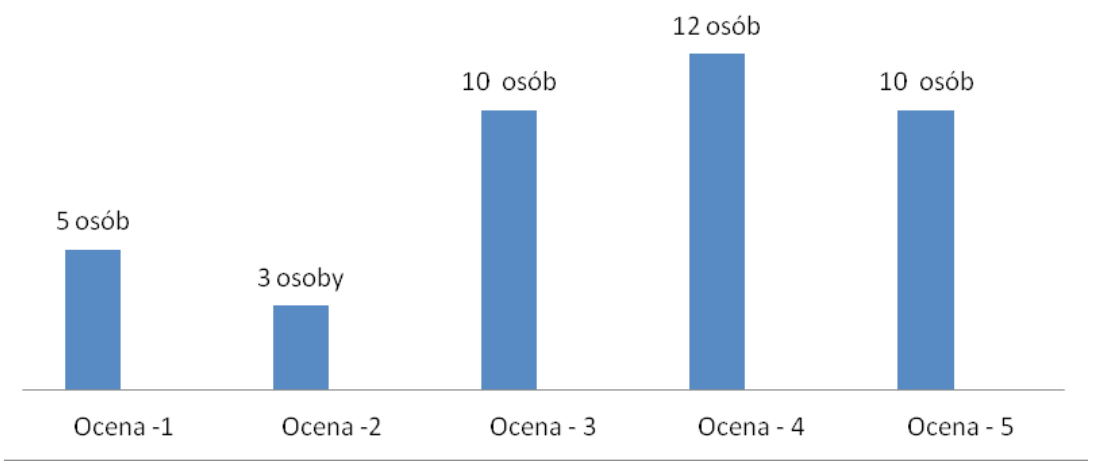

Ryc. 2. Ocena poziomu realizacji celów odbywanej praktyki:

"Zapoznanie się z procedurą projektowania przez nauczyciela działań edukacyjnych i wychowawczo-opiekuńczych"

(Źródło: opracowanie własne na podstawie przeprowadzonych badań) 
- brak spotkań warsztatowych przygotowujących studentów np. do nawiązywania relacji z grupą, czy zachowań w sytuacji trudnej;

- nieuzgadnianie terminu realizacji przedmiotu ze studentami.

Następne pytanie dotyczyło oceny (w skali 5-stopniowej, gdzie 1 to ocena najniższa, zaś 5 - ocena najwyższa) przez studentów poziomu realizacji poszczególnych celów odbywanej praktyki. Pierwszy to: zapoznanie się z procedurą projektowania przez nauczyciela działań edukacyjnych i wychowawczo-opiekuńczych. Czterech respondentów oceniło ten punkt negatywnie przyznając notę najniższą - 1 , dwóch oceniło na 2 , średni stopień zadowolenia - 3 wskazało osiem osób, natomiast ocenę 4 przyznało szesnaście osób, a najwyższą notę 5 dało dziesięć osób.

Kolejny punkt dotyczył nabywania przez studentów umiejętności samodzielnego planowania i prowadzenia zajęć dydaktycznych. Pięć osób oceniło realizację tego celu negatywnie przyznając notę 1 , trzy osoby dały ocenę 2 , dziesięć osób - 3, natomiast ocenę dobrą - 4 przyznało dwanaście osób, a ocenę bardzo dobrą - 5 dziesięć osób.

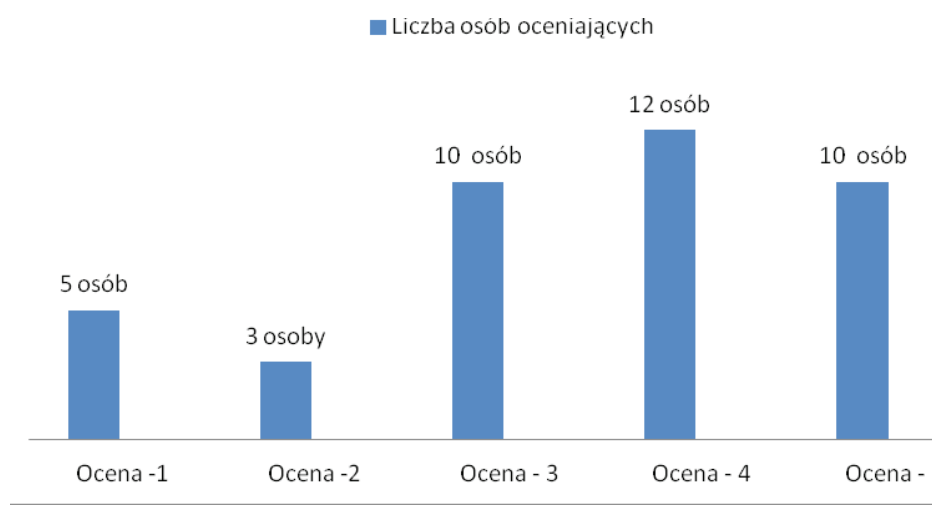

Ryc. 3. Ocena poziomu realizacji celów odbywanej praktyki:

„Nabycie umiejętności samodzielnego planowania i prowadzenia zajęć dydaktycznych"

(Źródło: opracowanie własne na podstawie przeprowadzonych badań)

Dalsze badane zagadnienie stanowił cel praktyki dotyczący podejmowania przez studentów działań opiekuńczo-wychowawczych. Cztery osoby oceniły realizację tego celu negatywnie, przyznając notę 1 . Dwie osoby wskazały notę 2, podobnie jak w przypadku oceny 3 - również dwie osoby. Aż szesnaście osób oceniło ten aspekt pozytywnie przyznając notę 4, a także szesnaście osób wskazało na bardzo dobre wyniki w tym obszarze, dając notę najwyższą -5. 


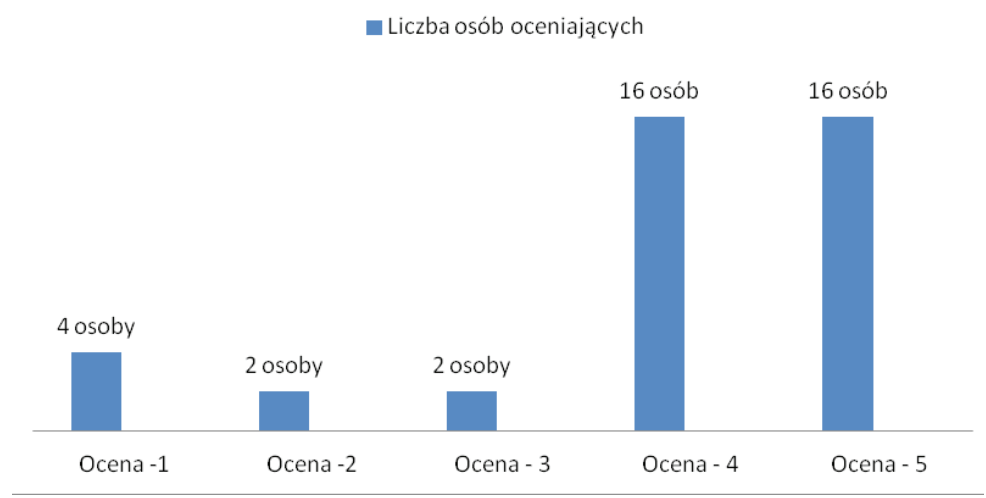

Ryc. 4. Ocena poziomu realizacji celów odbywanej praktyki:

„Podejmowanie działań opiekuńczo-wychowawczych

(Źródło: opracowanie własne na podstawie przeprowadzonych badań)

Następny cel realizowanej praktyki stanowiło zapoznanie się z programem i planem pracy nauczyciela. Cztery osoby oceniły ten aspekt zaznaczając cyfrę 1 . Dwie osoby przyznały notę 2 . Notę 3 wskazało ośmiu respondentów, natomiast 4 i 5 - po trzynastu respondentów. Dane te prezentuje rycina 5.

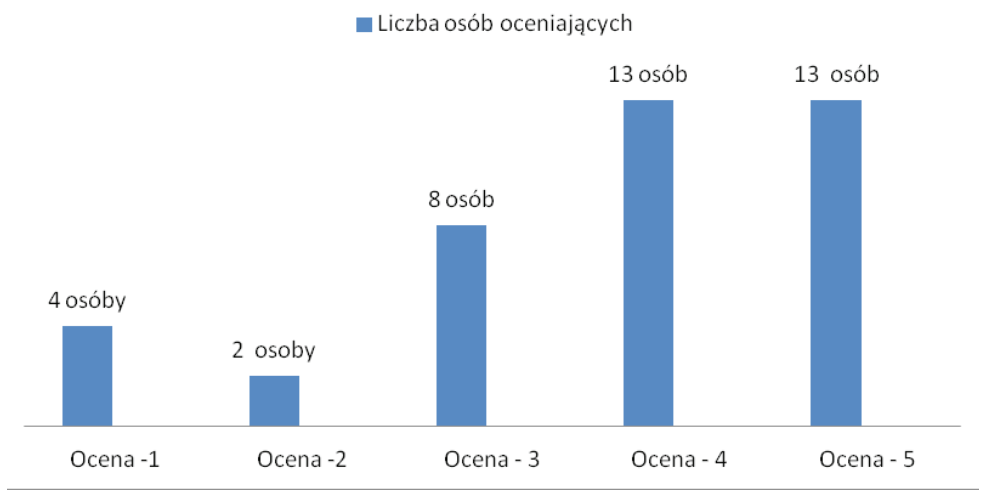

Ryc. 5. Ocena poziomu realizacji celów odbywanej praktyki:

"Zapoznanie się z programem i planem pracy nauczyciela"

(Źródło: opracowanie własne na podstawie przeprowadzonych badań)

Kolejne pytanie dotyczyło poziomu realizacji celu, który brzmiał: „Zapoznanie się z działaniami podejmowanymi na rzecz dzieci i młodzieży z trudnościami w funkcjonowaniu psychospołecznym". Siedem osób przyznało w tej 
kategorii notę najniższą - 1, cztery osoby wskazały ocenę 2, osiem osób poziom realizacji tego celu określiło oceną 3, również osiem osób przyznało ocenę 4, natomiast trzynaście osób realizację tego celu oceniło bardzo dobrze, dając notę 5 .

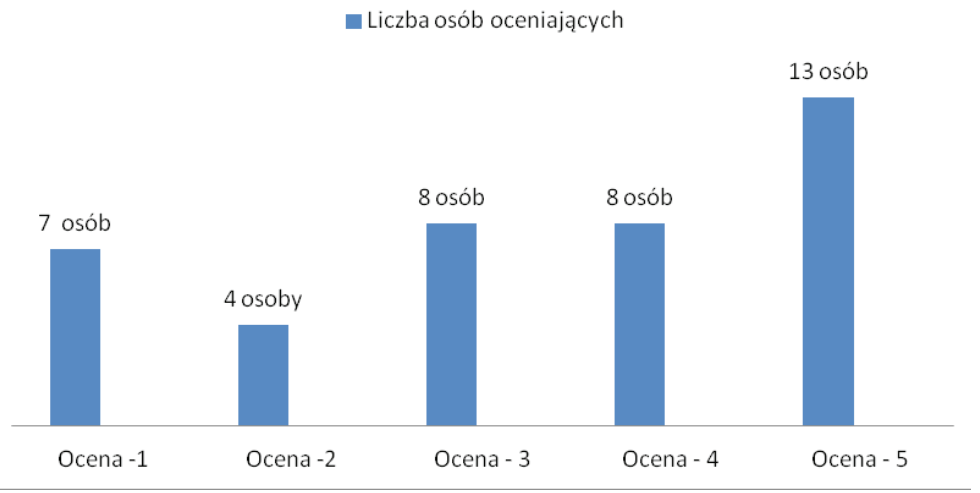

Ryc. 6. Ocena poziomu realizacji celów odbywanej praktyki:

„Zapoznanie się z działaniami podejmowanymi na rzecz dzieci i młodzieży z trudnościami w funkcjonowaniu psychospołecznym"

(Źródło: opracowanie własne na podstawie przeprowadzonych badań)

Następny punkt dotyczył oceny form pomocy psychologiczno-pedagogicznej dla dzieci z trudnościami w funkcjonowaniu psychospołecznym, realizowanych na terenie placówek, w których odbywano praktyki studentów. Pięciu ankietowanych przyznało ocenę najniższą - 1, siedem osób wskazało notę 2, również siedem - ocenę 3, trzynaście osób przyznało ocenę 4, zaś osiem - ocenę 5 .

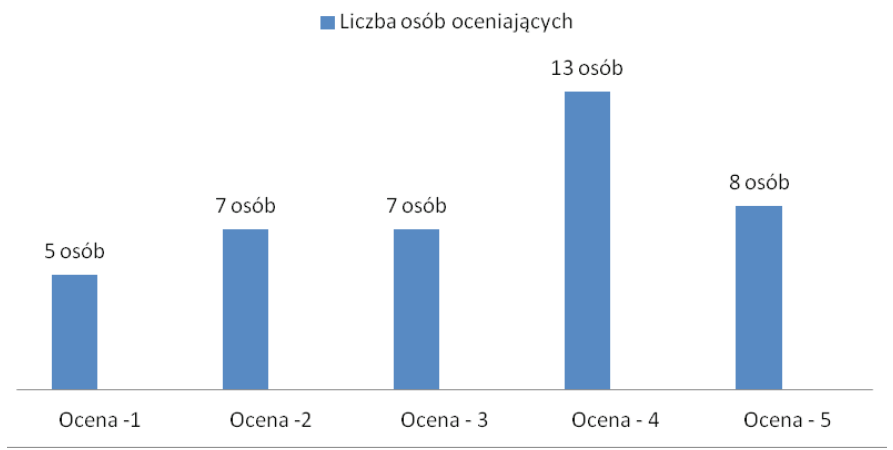

Ryc. 7. Ocena poziomu realizacji celów odbywanej praktyki: „Organizacja form pomocy psychologiczno-pedagogicznej funkcjonujących na terenie placówki”

(Źródło: opracowanie własne na podstawie przeprowadzonych badań) 
Ostatnie pytanie z serii dotyczącej realizacji celów zawartych w regulaminie praktyk dotyczyło możliwości samodzielnego planowania i przeprowadzania zajęć. Ocenę najniższą - 1 przyznało pięć osób, ocenę 2 - dwie osoby, ocenę 3 - dziewięć osób oraz ocenę 4 - dwanaście osób i ocenę 5 - również dwanaście osób.

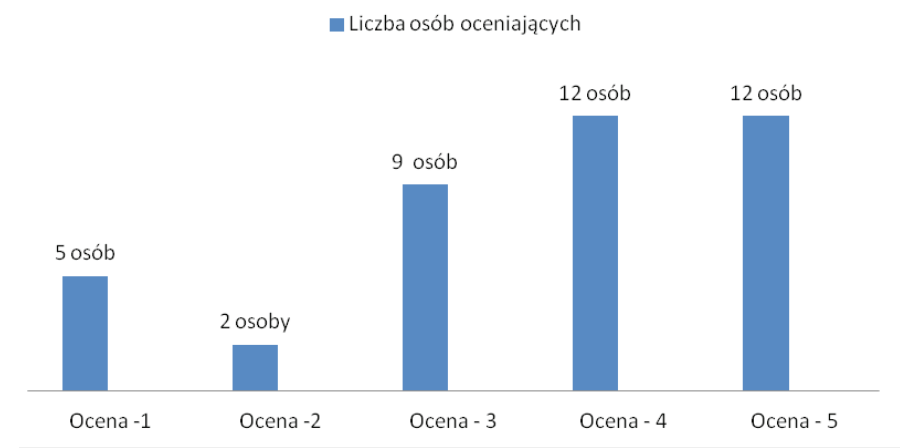

Ryc. 8. Ocena poziomu realizacji celów odbywanej praktyki: „Możliwość samodzielnego planowania i prowadzenia zajęć"

(Źródło: opracowanie własne na podstawie przeprowadzonych badań)

Podsumowując serię pytań dotyczących realizacji celów praktyki pedagogicznej, zauważyć można, iż większość studentów jest zadowolona z ich realizacji i przyznaje oceny najwyższe -4 lub 5 . Wiele osób daje również ocenę średnią - 3, jednak niepokoić powinno przyznawanie przez studentów ocen negatywnych - 2 i 1 . Istotne wydaje się poszukiwanie przyczyn tego stanu rzeczy oraz konieczność refleksji nad możliwościami ich zmiany.

Podczas badań interesował nas również stosunek studentów do wymiaru czasowego realizowanych praktyk. W tym aspekcie zdania są podzielone. Dwadzieścia osób uważa, iż nie powinien zostać on zmieniony, natomiast drugie dwadzieścia dostrzega konieczność zmian w tym zakresie. Wśród osób proponujących zmiany cztery wskazują chęć zmniejszenia wymiaru godzin praktyk, natomiast szesnaście podkreśla, iż powinny zostać one zwiększone. Propozycje studentów są bardzo różne i dotyczą zarówno dodania godzin realizowanych praktyk (od 10 dodatkowych godzin przez 80, 90, 100, a nawet 200), jak i zmniejszenia wymiaru praktyk do 40, 50 oraz 100 godzin. Część studentów opowiadała się po stronie zwiększenia lub zmniejszenia wymiaru godzin praktyk, jednak nie potrafili sprecyzować, ile godzin praktyk powinno ich obowiązywać - ile godzin by ich satysfakcjonowało.

Na koniec tej części poproszono studentów o wskazanie zadań realizowanych w ramach praktyk, które ich zdaniem wymagają zmiany oraz przedsta- 
wienie propozycji rozwiązań własnych. Wskazywano na takie aspekty, jak: dostosowanie form realizacji zadań podczas praktyk do możliwości studenta i placówki, nakierowanie zadań w większym stopniu na samodzielną pracę studenta, dokładniejszy i bardziej szczegółowy opis praktyk (wymiar godzin, termin realizacji, proponowane placówki, cele itp.), termin realizacji. Zdaniem studentów, praktyki nie powinny odbywać się w trakcie trwania roku akademickiego, gdyż odbywa się to kosztem zajęć; konkretne zadania nakierowane są na zastosowanie wiedzy teoretycznej w praktyce - kompetencja, wiedza i właściwe przygotowanie osób prowadzących przedmiot: „Przygotowanie do praktyki".

Dla prowadzących badanie ważny był również temat dotyczący współpracy z nauczycielem/pedagogiem, który powinien pełnić nie tylko funkcję opiekuna praktyk, ale przede wszystkim mentora przyszłego nauczyciela. Poproszono zatem studentów o dokonanie oceny także tego aspektu. Na pytanie to studenci mieli możliwość wyboru jednej z czterech opcji:

1) Jest bardzo dobra.

2) Jest dobra.

3) Oczekiwałbym/Oczekiwałabym większego wsparcia ze strony opiekuna, ale współpracę oceniam pozytywnie.

4) Nie jestem zadowolony/a, ponieważ...

Oto odpowiedzi udzielone przez badanych studentów.

- Liczba osób oceniających

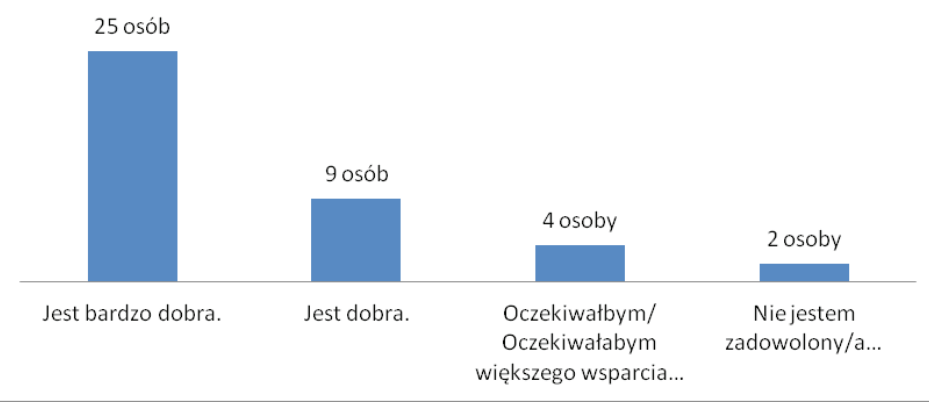

Ryc. 9. Ocena współpracy z nauczycielem/pedagogiem opiekunem praktyk w placówce dokonana przez studentów

(Źródło: opracowanie własne na podstawie przeprowadzonych badań)

Można zauważyć, iż znacząca liczba badanych - aż dwadzieścia pięć osób - ocenia swoją współpracę z opiekunem praktyk jako bardzo dobrą. Dziewięć osób wskazuje, iż jest ona dobra, natomiast cztery osoby oczekiwałyby więk- 
szego wsparcia ze strony opiekuna, ale współpracę ocenia pozytywnie, natomiast dwie osoby nie są zadowolone ze współpracy. W uzasadnieniu kontynuującym odpowiedź 4.: „Nie jestem zadowolony/a, ponieważ...” pojawiają się takie sformułowania jak: „Mała uwaga opiekuna, brak czasu i zainteresowania z jego strony”, „W jednej z placówek wszelkie konsultacje z nauczycielem odbywały się w biegu, z powodu braku czasu pojawił się nawet problem ze wskazaniem obszaru, który miałam przeprowadzić na zajęciach”, "Zazwyczaj spotykam się z tzw. »machnięciem ręką i odesłaniem do ostatniej ławki, by praktykant po prostu nic nie robił i nie oczekiwał zaangażowania od opiekuna praktyk. Praktykant jest traktowany jak irytujący uczeń - za dużo chce, więc lepiej go odesłać, by o nic nie prosił".

Budujący jest fakt, iż studenci dostrzegają wiele korzyści wynikających z realizacji praktyk pedagogicznych. Oto przykładowe opinie: „jest to sfera praktyczna, która pomaga zrozumieć i poznać prawdziwe realia pracy z dziećmi”, ,poznanie praktycznych zachowań w różnych sytuacjach w przedszkolu i szkole", ,jest to nieocenione doświadczenie, pozwalające na konfrontację rzeczywistości z teorią", szansa na zdobycie nowej wiedzy i umiejętności, możliwość dostrzeżenia problemów występujących w rzeczywistości edukacyjnej, „możliwość doświadczenia »na żywo« kontaktu z grupą dzieci, sprawdzenia w praktyce, które metody są skuteczne w pracy z określoną grupą, powiązanie wiedzy teoretycznej zdobytej na zajęciach, z praktyką, zweryfikowanie własnych preferencji zawodowych, uzyskanie prawdziwego obrazu funkcjonowania dzieci z określonymi zaburzeniami w danym wieku rozwojowym", „jest to możliwość samodzielnego planowania i prowadzenia zajęć”, ,jest to możliwość sprawdzenia się w roli nauczyciela i zweryfikowania swojego wyboru kierunku studiów”, „jest to szansa na zaobserwowanie, jak pracuje się z poszczególnymi dziećmi, w jaki sposób postępować, co robić, a czego nie robić. Ważne jest także to, że uczymy się przezwyciężać trudne momenty, które zdarzają się każdemu i w ostateczności potrafimy przez to przebrnąć".

Opisując osobiste doświadczenia, studenci w wywiadach narracyjnych koncentrowali się jednak przede wszystkim na wydawałoby się zapominanej relacji „mistrz-uczeń".

(...) Wejście do przedszkola to byt dla mnie ogromny stres, bo już na samym początku opiekunka moich praktyk - nauczyciel dyplomowany - stwierdziła, że jestem kolejna praktykantka i znowu będzie musiała "coś mi tam pokazać". Nie ma na to za dużo czasu, bo dzieci sa teraz coraz trudniejsze, nieciekawie układa sie też wspótpraca z rodzicami (...). Dzieci okazały się fantastyczne, choć bardzo żywiołowe. Zaproponowatam, że poprowadze zajęcia ruchowe, moge też wprowadzić inne elementy aktywności fizycznej, ale pani stwierdziła, że przede wszystkim trzeba skupić się na przygotowaniu do szkoły (to w końcu sześciolatki!). Najwięcej czasu na prakty- 
ce przeznaczyta mi na wykonywanie pomocy dla dzieci, w tym kserowanie gotowych kart pracy (...). Przychodziłam do tej grupy $i$ widziałam często znudzone i niezainteresowane dzieci, dobrze, że choć z nimi udało mi się nawiązać fajny kontakt, zapraszały mnie np. do zabaw i prosity, by im poczytać. Zupetnie inaczej przyjęła mnie nauczycielka w tym samym przedszkolu, pracująca z inna grupa 6-latków. Pytała, co chciatabym zrealizować z dziećmi, co umiem, wspólnie ustalityśmy jakie zajęcia moge próbować prowadzić samodzielnie. To była też niemłoda nauczycielka, ale widać było z jaka pasją pracuje z dziećmi. Nie zauważyłam, by miała "problemy z rodzicami", ale też często poświęcała im swój czas (...). [Marta, II rok studiów]

(...) Idąc na praktyke do szkoty specjalnej, czułam się niezbyt dobrze przygotowana, mimo że był to kolejny raz, jednak poprzednio niewiele się nauczyłam - chyba jedynie tego, że między teorią a praktyka jest przepaść. Skierowano mnie też do "wyjatkowo trudnej grupy" prowadzonej przez pania X. Jednak pani X, do której trafitam, upewnita mnie swoja praca i relacją z dziećmi z niepetnosprawnościa, że to jest moje miejsce. Na początku bytam przestraszona, bo jedno dziecko byto wyjatkowo agresywne, ale Ona pokazała, co robić w takiej sytuacji. Zobaczyłam też, jak madrze trzeba wybierać różne metody pracy z tymi dziećmi - to było zupetnie coś innego niż na uczelni. A potem trafitam do innej grupy i innej nauczycielki, i zaczęłam mieć wątpliwości, czy w ogóle się nadaję do zawodu pedagoga specjalnego, bo cokolwiek zrobiłam zawsze byto kończone stwierdzeniem "no i czego oni was na tym uniwersytecie ucza (...) nie wiem czy sobie poradzisz w tym zawodzie..." tu nastepowato wymienienie tego wszystkiego, czego nie umiem (...). Dobrze, że miałam możliwość powrotu do pani Ewy i jej „wyjątkowo trudnej grupy”. [Katarzyna, III rok studiów]

Podsumowując otrzymane wyniki badania ankietowego, można stwierdzić, iż wielu studentów jest zadowolonych z realizacji przedmiotu „Przygotowanie do praktyki", a także odbywania samej praktyki, jednak należy zwrócić uwagę na fakt, iż jest grupa osób oceniających poszczególne punkty notami najniższymi - 1 i 2 . Do refleksji powinny też skłonić wypowiedzi studentów. W dalszym ciągu, pomimo że dyskusja na temat istoty i sposobów realizacji praktyk, jako jednego z podstawowych elementów programu studiów, trwa nieprzerwanie od wielu lat, potrzebne są, oparte na pogłębionej ewaluacji, zmiany sprzyjające rozwojowi kompetencji przyszłych nauczycieli.

\section{Dyskusja i wnioski}

Analiza prowadzonych w Polsce badań wskazuje, że w polskich przedszkolach i szkołach tkwi znaczny potencjał związany z psychofizycznymi zasobami dzieci, gotowością nauczycieli do uczenia się, a także z rosnący- 
mi aspiracjami i dążeniami edukacyjnymi społeczeństwa. Urzeczywistnienie tego potencjału zależy jednak w dużej mierze od jakości edukacji dzieci w wieku przedszkolnym i wczesnoszkolnym, która w sposób bezwzględny związana jest z wysokimi kompetencjami nauczycieli edukacji elementarnej, jako że w tym okresie tworzą się podstawy edukacyjnej przyszłości i poczucia sukcesu.

Wymaga to wysiłku wszystkich uczestników edukacji dziecka, wytężonej współpracy i działania w poczuciu odpowiedzialności za osiągane efekty, systematycznego doskonalenia własnej pracy przez nauczycieli-praktyków, ale też przygotowujących się do bycia nauczycielem o wysokich kompetencjach osobistych i zawodowych studentów pedagogiki. To ich zadaniem będzie w przyszłości tworzenie takich strategii edukacyjnych, które będą nastawione na optymalny rozwój każdego dziecka. Jednak, by urzeczywistnieniu uległo marzenie wielu studentów bycia nauczycielem kompetentnym, musi zostać spełniony warunek implementacji wiedzy teoretycznej do praktyki pedagogicznej. Jest to możliwe tylko wówczas, kiedy w czasie praktyki pedagogicznej w przedszkolu i szkole będą mogli, ze wsparciem nauczyciela-mentora, podejmować i realizować wyzwania sprzyjające zdobywaniu nowych doświadczeń pozwalających poszerzać kompetencje psychopedagogiczne i metodyczne, po to by stawać się nauczycielem, który będzie w stanie sprostać wyzwaniom ponowoczesności.

Wydaje się, że podjęte przez nas badania sygnalizują jednak nie tylko kilka ważnych obszarów, istotnych w budowaniu kompetencji psychopedagogicznych i metodycznych przez studentów, ale zdają się też generować kolejne pytania dotyczące choćby celów mentoringu nauczycielskiego w pracy ze studentem realizującym praktykę pedagogiczną, czy tworzenia takich pól aktywności opartych na współdziałaniu: nauczyciel akademicki (opiekun praktyk studenckich) student (przyszły nauczyciel) nauczyciel przedszkola/ szkoły, dzięki którym student będzie odczuwał realność stawania się kompetentnym nauczycielem. Taki wymóg stawia przed nami Edukacja $4.0^{10}$

\section{BIBLIOGRAFIA}

Chauval D., Casanova A.M., Podręcznik przedszkolanki, Wydawnictwo Cyklady, Warszawa 1998.

Fisk P., Education 4.0 ... the future of learning will be dramatically different, in school and throughout life. http://www.thegeniusworks.com/2017/01/future-education-young-everyone-taught-together/ [dostęp: 11.10.2018].

${ }^{10}$ P. Fisk, Education $4.0 \ldots$ the future of learning will be dramatically different, in school and throughout life. http://www.thegeniusworks.com/2017/01/future-education-young-everyone-taught-together/ [dostęp: 11.10.2018]. 
Gnitecki J., Kompetencje i zwiększanie szans edukacyjnych nauczycieli w cyklu życia w warunkach postępujacej globalizacji, [w:] W poszukiwaniu wyznaczników kompetencji nauczyciela XXI wieku, red. E. Kobyłecka, E. Kozioł, Wydawnictwo Uniwersytetu Zielonogórskiego, Zielona Góra 2002.

Kozioł E. (red.), W poszukiwaniu wyznaczników kompetencji nauczyciela XXI wieku, Wydawnictwo Uniwersytetu Zielonogórskiego, Zielona Góra 2002.

Krauze-Sikorska H., Dzieci i młodzież z ryzyka niepowodzeń w uczeniu się w przestrzeni edukacyjnej i społecznej szkoty powszechnej. Systemowe strategie pomocy - (nie)nowe wyzwania, nowe perspektywy - materiał niepublikowany (za zgodą autora) 2018.

Ordon U., Nauczyciel w przestrzeni edukacyjnej jednoczacej się Europy, Wydawnictwo im. Stanisława Podobińskiego Akademii im. Jana Długosza, Częstochowa 2007.

Pasterniak W., Od małego ego do madrości. O antykompetencjach i kompetencjach edukacyjnych nauczycieli, [w:] W poszukiwaniu wyznaczników kompetencji nauczyciela XXI wieku, red. E. Kobyłecka, E. Kozioł, Wydawnictwo Uniwersytetu Zielonogórskiego, Zielona Góra 2002.

Potyrała B., Przełom wieków wyzwaniem dla edukacji i nauczyciela, [w:] W poszukiwaniu wyznaczników kompetencji nauczyciela XXI wieku, red. E. Kobyłecka, E. Kozioł, Wydawnictwo Uniwersytetu Zielonogórskiego, Zielona Góra 2002.

Radziewicz J., Autoportret pedagogiczny, Edukacja i Dialog, 1996, 4.

Styczyńska M., Rola mężczyzny w wychowaniu dziecka w wieku przedszkolnym, [w:] Dziecko, sukcesy i porażki, red. R. Piwowarski, Instytut Badań Edukacyjnych, Warszawa 2007.

Szorc K., Kompetencje nauczyciela na miare XXI w., 2005, zob: http:/ / konferencja.21.edu.pl/ publikacje/1/360.pdf [dostęp: 17.04.2018]. 